UDK 75.052(477.75)+72.684(477.75)

Submitted: 18.03.2019

LBC 63.3(0)4

Accepted: 05.07.2019

\title{
REASSESSING THE PERIOdIZATION OF MURAL PAINTINGS IN THE CAVE CHURCH OF THE SOUTHERN MANGUP MONASTERY
}

\author{
Yuriy M. Mogarichev \\ Institute of Archaeology of Crimea of the Russian Academy of Sciences, Simferopol, Russian Federation; \\ Crimean Republican Institute of Postgraduate Pedagogical Education, Simferopol, Russian Federation
}

\author{
Alena S. Ergina \\ Saint Petersburg Stieglitz State Academy of Art and Design, Saint Petersburg, Russian Federation
}

\begin{abstract}
Introduction. The Southern Monastery is located in the southern part of the Mangup plateau in a natural rock grotto. The cave church is in the eastern side of the grotto. It is decorated with mural paintings. The murals of the church are concentrated in the altar. Frescos are divided into the images on the apse, on the altar arch and on the vaults of the church. Methods. Authors give the periodization of frescos comparing iconography and stylistics. Analysis. The images on the apse are flat. The eaves of the altar arch are similar to the icon row. Saints on the arches of the church have their original compositional solution. The apse's painting was formed earlier than other architectural divisions of the church interior. The fundamentally different organization of the tectonics of the pictorial surface of the altar arch eave and vaults suggests that different artists made these images at short intervals. Results. The church's murals of the Southern Mangup Monastery were probably formed in three stages. Different artists, who were the representatives of various eastern Christian schools of sacred painting, made the murals. Due to the closed compositional scheme the painting system appears as an indissoluble whole, despite the definite duration of the murals' formation in the church of the Southern Mangup Monastery. In general, the paintings of the church of the Southern Mangup Monastery date from the early - the third quarter of the $15^{\text {th }}$ century. Probably this monastery is associated with the ruling dynasty of Theodoro.
\end{abstract}

Key words: Byzantium, Crimea, Mangup, Southern monastery, frescoes.

Citation. Mogarichev Yu.M., Ergina A.S. Reassessing the Periodization of Mural Paintings in the Cave Church of the Southern Mangup Monastery. Vestnik Volgogradskogo gosudarstvennogo universiteta. Seriya 4. Istoriya. Regionovedenie. Mezhdunarodnye otnosheniya [Science Journal of Volgograd State University. History. Area Studies. International Relations], 2019, vol. 24, no. 6, pp. 47-63. (in Russian). DOI: https://doi.org/10.15688/ jvolsu4.2019.6.4

УДК 75.052(477.75)+72.684(477.75)

ББК 63.3(0)4

Дата поступления статьи: 18.03.2019

Дата принятия статьи: 05.07.2019

\section{К ВОПРОСУ О ПЕРИОДИЗАЦИИ ФРЕСКОВЫХ РОСПИСЕЙ ПЕЩЕРНОЙ ЦЕРКВИ ЮЖНОГО МОНАСТЫРЯ МАНГУПА}

\author{
Юрий Миронович Могаричев \\ Институт археологии Крыма РАН, г. Симферополь, Российская Федерация; \\ Крымский республиканский институт постдипломного педагогического образования, \\ г. Симферополь, Российская Федерация
}

\section{Алена Сергеевна Ергина}

Санкт-Петербургская государственная художественно-промышленная академия им. А.Л. Штиглица, г. Санкт-Петербург, Российская Федерация 
Аннотация. Введение. Южный монастырь расположен в южном обрыве плато Мангупа в естественном скальном гроте. В восточной стороне грота находится пещерная зальная церковь, которая была украшена фресковой росписью. Комплекс с точки зрения планировочных решений является цельным. Стенопись церкви сконцентрирована в алтарной части и разделена на композиции апсиды, роспись карниза алтарной арки, изображения святых на сводах церкви. При оформлении интерьера этого храма перед художником стояла задача - учитывая движение глаз зрителей, участвующих в литургических обрядах, скомпоновать изображение внутри архитектурных членений в небольшой по объему пещерной церкви и при этом не разрушить плоскость изображения. Meтоды. Авторы рассматривают периодизацию фресковых росписей путем сопоставления иконографии и стилистики изображений. Анализ. Изображения на апсиде носят плоскостно-графический характер. Карниз алтарной арки подобен иконному ряду. Образы святых на сводах церкви имеют свое оригинальное композиционное решение. Роспись апсиды сформировалась раньше других архитектурных членений интерьера церкви. Принципиально разная организация тектоники изобразительной поверхности карниза алтарной арки и сводов позволяет предположить, что данные изображения выполнены через небольшие промежутки времени разными художниками, предположительно представителями одной школы живописи, возможно итало-греческой. Результаты. Роспись церкви Южного монастыря Мангупа формировалась, вероятно, в три этапа. Стенопись была исполнена разными художниками, представителями различных восточнохристианских школ сакральной живописи. Несмотря на определенную длительность формирования стенописи церкви Южного монастыря Мангупа, система росписи предстает как нерасторжимое целое ввиду его замкнутой композиционной схемы. В целом росписи церкви Южного монастыря Мангупа датируются в пределах начала - третьей четверти XV века. Вероятно, данный монастырь связан с правящей династией Феодоро. В рамках настоящей работы Ю.М. Могаричев исследовал проблемы архитектурных особенностей церкви южного монастыря, хронологии памятника и исторического контекста его появления и функционирования. А.С. Ергина выполнила формально-стилистический и иконографический анализ сохранившихся фрагментов фресковых росписей.

Ключевые слова: Византия, Крым, Мангуп, Южный монастырь, фрески.

Цитирование. Могаричев Ю. М., Ергина А. С. К вопросу о периодизации фресковых росписей пещерной церкви Южного монастыря Мангупа // Вестник Волгоградского государственного университета. Серия 4, История. Регионоведение. Международные отношения. - 2019. - T. 24, № 6. - С. 47-63. - DOI: https:// doi.org/10.15688/jvolsu4.2019.6.4

Введение. Поселение на плато горы Мангуп (рис. 1) известно в период раннего Средневековья как Дорос, а в XIV-XV вв. Феодоро. Во второй половине VI в. по инициативе византийской администрации здесь возводится крепость. В 80-х гг. VIII в. Мангуп на короткий период был захвачен хазарами. К середине IX в. крепость вновь переходит в подчинение византийской администрации и включается в фему Климатов (в 50-х гг. IX в. переименованную в фему Херсон). В середине второй половине ХІ в. городище приходит в упадок, который продолжался до XIV века. К середине XIV в. поселение, которое стало называться Феодоро, становится столицей одноименного княжества, находившегося первоначально под контролем золотоордынских наместников полуострова. Здесь формируется городская застройка, создается цитадель на мысе Тешкли-Бурун. Однако уже в конце этого столетия оно было разорено войсками самаркандского правителя Тимура. Начиная с первой четверти XV в. восстановленный город входит в период наивысшего расцвета. В 2030-е гг. здесь проводятся крупные строительные работы, в том числе возводится новый оборонительный рубеж - Вторая линия обороны, реконструируется цитадель, значительно обновляется базилика, сооружаются дворец правителей и княжеская церковь в цитадели (октагон), обновляются и расширяются пещерные монастыри и храмы. В 1475 г. Феодоро был захвачен турками-османами. В 70-х гг. XVIII в. турки покинули крепость, а в 1792 г. отсюда ушли и последние жители - караимы (подробнее о Мангупе см.: $[1 ; 3 ; 4 ; 5$, с. $461-470 ; 7 ; 18$, с. 5357 ; 19, с. 120-144]).

В мангупской историографии внугрискальные памятники, как «лежащие на поверхности», архитектурно выразительные и относительно хорошо сохранившиеся традиционно занимают важное место. При этом первенство среди пещерных сооружений Мангупа принадлежит культовым памятникам, а именно пещерным церквям и монастырям ([2; 8, с. 119-125; 19, c. $54-76 ; 20$, с. $131-140$, с. $144 ; 21$, с. $79-81])$. 
Особое внимание заслуживает так называемый Южный монастырь. Памятник расположен в южном обрыве плато (рис. 1, 9). В монастырь из небольшого естественного грота в основании обрыва ведет искусственный туннель. Проход заканчивается на краю площадки еще одного естественного грота в средней части обрыва. В восточной стороне грота была вырублена пещерная зальная церковь (рис. 2). В период функционирования церковь была украшена фресками, которые покрывали апсиду с нишей и конхой, арку, окаймляющую алтарь и фриз над аркой. Комплекс представляется цельным с точки зрения планировочных решений. В храме монастыря не видно заметных переделок и перепланировок. Немногочисленный археологический материал, обнаруженный при зачистке монастыря, датируется XIV-XV вв. $[2$, c. $21-26,37-41 ; 8$, c. $123-124 ; 9 ; 19$, c. 64-66, $71-73 ; 20$, с. $138-139 ; 21$, с. $80-81]$.

Методы. Несмотря на то что Южный монастырь и его пещерная церковь являются одним из «символов» Мангупа и часто, уже со второй половины XIX в., упоминаются в путеводителях и иной популярной литературе, посвященных им серьезных научных публикаций известно не много.

Первое подробное описание памятника (равно как и вообще первое упоминание) выполнил А.С. Уваров во время научной поездки на Юг России в 1848 году. По мнению исследователя, сначала, в период гонений на христиан, в данном месте был вырублен небольшой храм с ведущей к нему лестницей, а после победы христианства церковь расширили [9, с. 180-181]. Сопровождавшим А.С. Уварова художником М. Вебелем было сделано несколько изображений памятников, вошедших в так называемый «Неизданный альбом Уварова», в том числе и два рисунка церкви Южного монастыря: изображения интерьера и фресок (рис. 3, 4).

В 1888 г. памятник попал в число объектов экскурсии Симферопольской мужской гимназии. Текст был проиллюстрирован рисунками А.А. Архипова. Один из них показывает в фас (развертка) алтарную часть церкви, где довольно четко, правда без проработки деталей, представлены основные сюжеты росписи. При этом не передан синтез архитектуры и живописи [24, с. 124-125].
В ноябре 1889 г. инженер Агеенко отправил в Археологическую комиссию чертежи и описания церкви Южного монастыря, а она, в свою очередь, обратилась в Таврическую ученую архивную комиссию с просьбой осмотреть памятник. Осмотр произвели известные крымские ученые А.Х. Стевен и А.И. Маркевич, которые датировали памятник XIV-XV вв. [12].

В 1890 г. в Известиях Таврической ученой архивной комиссии А.И. Маркевич поместил статью «Экскурсия на Мангуп», в которой много места было уделено и рассматриваемому объекту [17, с. 105-107]. Автор отметил лучшую сохранность фресковых росписей по сравнению с другими подобными памятниками Крыма: «До сих пор уцелели греческие надписи с именами святых, напр. Феодора, Параскевы и др.; во многих местах хорошо сохранились краски, а также позолота, которой покрыты и надписи. Все иконы греческого письма» $[17$, с. 106]. Тот же А.И. Маркевич указывал на хорошую сохранность фресок еще в 1911 г., после посещения ряда «пещерных городов» [25, с. 35].

В.В. Латышев в Записках Одесского общества истории и древностей (т. 20) опубликовал работу «Заметки к христианским надписям из Крыма», где, основываясь на данных А.Л. Бертье-Делагарда, упомянул надписи, сохранившиеся тогда на фреске церкви Южного монастыря. Среди имен под изображениями святых он отмечал «св. Григория, Феодора, арх. Гавриила и Михаила, Параскеву, Марину, Иоанна и Марию» [16, с. 154].

Изображения были описаны и в путеводителе по Крыму 1914 г.: «...фрески испещрены подписями, лики выковыряны за исключением немногих, но по остаткам можно восстановить сюжеты росписи» $[15$, c. 269-270].

Детальное описание памятника поместил Н.И. Репников в неопубликованных «Материалах к археологической карте Юго-Западного нагорья Крыма». По стилистическим особенностям росписей исследователь датировал церковь и ее росписи концом XIV в. [26, л. 230-231].

И.Е. Грабарь в 1927 г. сделал зарисовки отдельных сюжетов фресковых композиций рассматриваемого храма. По его мнению, 
роспись была создана в XIV в., а в XVXVI вв. обновлялась [11, с. 256].

В 1966 г. О.И. Домбровский опубликовал труд «Фрески средневекового Крыма», четвертая глава которого посвящена церкви Южного монастыря [13, с. 78-89]. Ученый датировал росписи концом XIV - XV в. [13, c. 88-89].

А.Г. Герцен и Ю.М. Могаричев детально проанализировали памятник в ряде своих работ. Они попытались сопоставить описание фресковых композиций Н.И. Репникова с предложенными коррекциями О.И. Домбровского, обратив внимание на уязвимые места концепции последнего. По их мнению, монастырь следует датировать первой половиной $\mathrm{XV}$ века. Возможно, он являлся семейной усыпальницей княжеской династии Феодоро [2, c. $21-26,37-41 ; 8$, c. $123-124 ; 9 ; 19$, c. $64-66$, 71-73; 20, c. $138-139 ; 21$, с. $80-81]$.

Е.М. Осауленко представил свое видение изображений в храме. По его мнению, храм был расписан приглашенными в начале XV в. из-за пределов Крыма (но не из Трапезунда) живописцами [23, с. 109].

Таким образом, в историографии прочно закрепилось представление о церкви Южного монастыря как о памятнике, время создания которого не выходит за пределы конца XIV первой половины XV века. Разногласия прослеживаются по следующим вопросам: перед нами единовременная роспись или фрески в период функционирования храма подновлялись (в ряде мест переписывались); кто и где изображен на композиции.

Целью настоящей работы является рассмотрение периодизации отдельных архитектурных членений рассматриваемого памятника путем сопоставления иконографии и стилистики изображений.

Анализ. Стенопись церкви Южного монастыря сконцентрирована в алтарной части и разделена на композиции апсиды, роспись карниза алтарной арки, изображения святых на сводах церкви. При оформлении интерьера данной церкви перед художником стояла задача - учитывая движение глаз зрителей, участвующих в литургических обрядах, скомпоновать изображение внутри архитектурных членений в небольшой по объему пещерной церкви и при этом не разрушить плоскость изображения. Важным также было гармонично связать изображаемые сюжеты между собой композиционно и выстроить религиозно-эстетическую идею всей системы росписей. В то же время необходимо было связать сюжеты с пространством интерьера церкви. Известно, что для средневековой живописи характерно не изображать художественными средствами реальные формы в пространстве, а аллегорически передавать символы веры [22, c. 13].

Композиция апсиды (рис. 5) содержит сюжеты «Деисус» и «Служба святых отец». В нише апсиды, которая обрамлена дугообразным выступом, запечатлено изображение Эммануила в медальоне.

Центральным сюжетом, отражающим литургическое значение всей системы росписей церкви Южного монастыря Мангупа, является композиция «Деисус», помещенная в конху апсиды. Что касается ее содержания, то наиболее убедительной, на наш взгляд, является интерпретация А.С. Уварова (напомним, он видел изображения в лучшем состоянии, чем последующие исследователи): направо от Спасителя - Богородица и Святой император Константин Великий, налево - Иоанн Креститель и Святая царица Елена, серафимы шестикрылые [9, с. 181].

У Спасителя сохранилась только нижняя часть лика (борода густая, разделенная на локоны, дугообразные усы и небольшой круглый подбородок), крещатый нимб цвета желтой охры, окаймленный белой полосой и темные, спадающие до плеч волосы. Трактовка изображения лика и рук плоскостная, колорит фигур светло-охристый. Образы представлены на темно-синем фоне светлыми силуэтами.

На плоскости алтарной апсиды по сторонам от ниши сохранились фрагментарные остатки сюжета «Служба святых отец». Наше натурное обследование памятника подтвердило версию О.И. Домбровского о содержании композиции: изображены святители во весь рост $[13$, с. $80-81]$. На северной стороне от ниши - Иоанн Златоуст, Григорий Богослов и две фигуры, которые не идентифицируются; на южной стороне от ниши - Василий Великий, Кирилл Александрийский и две фигуры, изображения которых совсем не сохранились. 
Фигуры святых отцов, облаченные в неяркие сероватые либо беловатые саккосы с черными орнаментированными вставками омофора, представлены в процессе богослужения. Незначительна роль темных орнаментальных вставок. Основной теплый белый тон доминирует и играет важную роль в формировании композиционного равновесия росписи и внутреннего архитектурного пространства церкви.

По справедливому замечанию Е.Н. Ocaуленко, изображение Эммануила в нише апсиды выступает единой композицией с сюжетом «Служба святых отец» и передает литургическое значение евхаристической жертвы Спасителя [23, с. 98]. В конхе ниши апсиды изображен процветший восьмиконечный крест с монограммой Христа - IC XC HI KA («Иисус Христос победитель»). Ниша обрамлена дугообразным выступом с синей широкой полосой и двумя красными полосами по сторонам. По белому фону ниши черной краской нанесен орнамент - греческий текст. Снизу остатки бахромы, что придает нише вид убруса - материи.

Необходимо отметить, что данные изображения носят исключительно плоскостно-графический характер. В произведениях сакральной монументальной живописи не предполагалась передача «линейного потока времени» от пошлого к настоящему, поэтому статические позы, которые фиксировали момент перехода от одной позы к другой, передавали стремление к движению. Застывшее движение использовалось художниками в качестве эффекта вечности. Такими изобразительными средствами, как линия, пятно, тон и цвет, используя плоскостной изобразительный метод, при котором с помощью крупных, ясных цветовых отношений, тяготеющих к противоположным цветам (синий - охра красная, лиловый - охра желтая), художник, оформляя архитектурные плоскости, передает ирреальный мир [22, с. 15]. Плоскостная трактовка ликов и яркий цвет одежд позволяют отметить некоторые сходства рассматриваемого памятника со стенописью монастыря Убиси (Грузия, конец XIV в.) (рис. 6). Близость проявляется в похожем синтезе архитектуры и сложного многофигурного сюжета «Деисус». Также, отметим общие черты с композицией «Деисус» в конхе апсиды церкви Дмитрия
Солунского в Каффе (XIV в.) (рис. 7). Здесь мы можем наблюдать определенные аналогии в атрибутах и деталях: орнаментальная отделка мебели и тканей одежд, трактовка нимбов, которые также имеют аналоги в стенописях, иконах и миниатюрах Византии XIV в. [13, с. 61-68]. О.И. Домбровский настаивал на отсутствии известных ему прямых аналогов росписи церкви Южного монастыря Мангупа. Тем не менее исследователь отметил фрески Перилевпты и Пантанассы в Мистре, а также икону Преображения (XIV$\mathrm{XV}$ вв.) в Третьяковской галерее и флорентийские иконы XIV-XV вв. из собрания Государственного Эрмитажа как произведения, близкие по трактовке формы в фигурах и колориту памятника [13, с. 83].

Изображения карниза алтарной арки церкви Южного монастыря Мангупа (рис. 8) контрастируют с изображениями апсиды и подобны иконному ряду, который характерен для иконостасов XV-XVI вв. [23, с. 94].

На замке тяги карниза центральный образ - Спас Нерукотворный («Убрус»). Изображенный на фоне плата лик Спасителя в византийской иконографии связывался с темой Воплощения, вследствие этого размещение живописного Убруса над престолом в алтаре храма отражает понимание образа как евхаристической жертвы [23, с. 96]. По обе стороны от образа Спаса Нерукотворного изображения святых воинов: правее - Архангел Михаил; левее - св. Георгий, один из двух святых Федоров (Федор Тирон или Федор Стратилат) и Дмитрий Солунский.

По обе стороны от «иконного ряда» А.С. Уваров видел две фигуры в полный рост - фигура сидящей Богоматери на фоне палаты, а соответствующая ей фигура на северном краю - Архангела Гавриила - уже в середине XIX в. была практически полностью утрачена [9, с. 181]. О.И. Домбровский подробно проанализировал данные изображения. Он выделял здесь часть крыла, нимб и надпись рядом с ним, которая свидетельствует, что не сохранилась фигура именно Архангела Гавриила. С противоположной стороны выделяется фигура Богоматери с пряжей на фоне архитектурного стаффажа [13, с. 78-89].

Таким образом, изображение Спаса Нерукотворного, которое перемещено в преде- 


\section{ВИЗАНТИЙСКАЯ ТАВРИКА}

лы алтарного пространства, объединяет других святых воинов. Оно по своему содержанию и глубинному смыслу становится центральным элементом композиции Благовещения, разделяя ее на две равные части.

Несмотря на то что иконография вышеперечисленных образов относится к иконописным традициям позднего XII - XIII в., мягкая тоновая лепка формы и густые оливковые тени в ликах, моделировка светотени светлой охрой отчетливо указывают нам, что автор данных изображений находился под влиянием реалистических тенденций, характерных для Итальянского Ренессанса. Отметим, что О.И. Домбровский так же указал на эту особенность: «Роспись этих участков явно сделана другой рукой и представляется несколько более поздней (по сравнению с росписями апсиды. - Ю. М., А. Е.)» [13, с. 83].

Изображения святых на сводах цер$\boldsymbol{\kappa} \boldsymbol{\varepsilon} \boldsymbol{u}$ (рис. 9) имеет оригинальное, отличное от предыдущих изображений, расположенных в апсиде и на карнизе алтарной арки, композиционное решение. Здесь центральный образ Богоматери типа «Знамение» с подписью Н ПАНАГІА помещен в медальон, а две фигуры в рост библейских пророков по обе стороны от медальона вписаны в декоративные аркосоли.

Поясное изображение Богородицы - с молитвенно воздетыми руками на красном фоне. На груди Богоматери медальон, в котором изображен Младенец Иисус Христос. Такая трактовка изображения Богородицы знак таинственного воплощения от Девы Марии всемогущего Бога. О.И. Домбровский указывает на одну особенность - опущенные веки Богородицы, приводя аналоги XIV в. и сопоставляя свободную интерпретацию данного образа с итальянской живописью XV в. $[13$, c. $86-87]$.

По обе стороны от Знамения - две фигуры в рост библейских пророков в царских облачениях [13, с. 86-87]. Е.Н. Осауленко предположил, что это пророк Моисей в образе царя аскета (на северном своде) и пророк Аарон (на южном своде) [23, с. 101].

Изображения на южной и северной стенах над сводом карниза алтарной арки сильно повреждены. А.С. Уваров на южной стене видел образы Св. Параскевы и Св. Марины
[9, с. 181]. Н.И. Репников изображений уже не видел в связи с утратами красочного слоя. Е.Н. Осауленко предположил, что на северной стене могло быть парное изображение полуфигур святых мужей [23, с. 109].

В образах святых на своде церкви просматривается нюансная передача формы. Наиболее наглядно это в моделировке ликов. В живописи лика Богородицы санкирь - цвет теней - формирует силуэт, а светлая охра путем постепенного перехода одного тона в другой моделирует объем. С помощью светотеневых и живописных средств передается ощущение иллюзорного объема.

О.И. Домбровский предположил, что росписи вне апсиды (карниз алтарной арки и своды церкви) выполнены в один промежуток времени: «Видимо, роспись тябла и плафона была выполнена одновременно, хотя, может быть, и не одним мастером» [13, с. 83].

Однако, как нам представляется, для организации изображений свода церкви характерно отличное от апсиды и росписи карниза алтарной арки композиционное решение. Плоскость свода разделена на геометрические формы, которые служили конструктивными элементами композиционного членения плоскости. Из этого следует, что композиционное решение карниза алтарной арки и свода складывалось в разный временной промежуток разными художниками.

Результаты. Таким образом, проанализировав фресковую роспись пещерной церкви Южного монастыря Мангупа, мы пришли к выводу, что в апсиде изображения древнее остальных. Они появились раньше, чем в других архитектурных членениях интерьера храма, и носят исключительно плоскостно-графический характер. Принципиально разная организация тектоники изобразительной поверхности карниза алтарной арки и сводов позволяет нам предположить, что росписи этих архитектурных членений выполнены не одновременно, а через небольшие промежутки времени разными художниками (сначала в карнизе арки, а затем на сводах), предположительно представителями одной школы живописи, возможно - итало-греческой.

При этом, несмотря на определенную длительность формирования стенописи церкви Южного монастыря Мангупа, система рос- 
писи предстает как нерасторжимое целое ввиду его замкнутой композиционной схемы: это передается с помощью равновесия - центральной симметрии. Смысловые точки тектонической структуры стремятся к центру, в котором сосредоточены главные религиозноэстетические идеи княжества Феодоро того времени.

Художникам удалось гармонично связать изображаемые сюжеты между собой композиционно благодаря общему густому синему цвету фона росписей, который использовали как при росписи апсиды, так и в росписях более позднего времени.

Можно предположить, что роспись церкви Южного монастыря Мангупа формировалась в три этапа. Она была исполнена разными художниками, представителями, возможно, различных восточнохристианских школ сакральной живописи. При этом мы не можем однозначно утверждать, что росписи второго и третьего этапов были нанесены поверх более ранних или на «голое» место.

Что касается датировки фресковых росписей, то на данном этапе исследования нет возможности определить их узкую хронологию и даже однозначно отнести их исключительно к XV веку. Однако наши представления об истории и культурных напластованиях Мангупского городища не позволяют считать XIV в. временем возможного появления церкви и фресок в ней. Уже во второй половине XIV в., вероятно с начала 60-х гг., письменные, археологические и эпиграфические источники фиксируют становление на плато Мангупа центра княжества, находившегося, скорее всего, в системе золотоордынских владений в Крыму [6]. Однако ни архитектурные особенности монастыря, ни фресковые роспи- си не позволяют выделить там следы тимуровского разгрома и последующего запустения, красочно описанного иеромонахом Матфеем [3, с. 580-587]. Поэтому, скорее всего, ранее упомянутая точка зрения А.Г. Герцена и Ю.М. Могаричева о датировке комплекса первой половиной XV в. и его связи с правящей династией Феодоро представляется наиболее аргументированной. Вероятно, монастырь был основан, а его церковь впервые расписана во время «строительного бума» 20 30-х гг. XV в., развернувшегося на Мангупе в период правления князя Алексея. Тогда существенно реконструируется цитадель, возводится Вторая линия обороны, основательно перестраивается базилика, строится дворец [7, c. 360]. Кроме того, были построены крепости Фуна и Каламита, реконструирована базилика в Партените [28, с. 111]. Соответственно, более поздние росписи могут датироваться периодом между 30-ми гг. XV в. и 1475 годом. Крайне маловероятно, что такое могло произойти после захвата столицы Феодоро турками-османами, когда погибло значительное число жителей города, а Мангуп превратился в центр кадылыка [7, с. 362-363; 27, с. 187264]. Если верна версия о связи Южного монастыря с княжеской династией Феодоро (или даже с представителями местной элиты), то, соответственно, каждый последующий ктитор обители должен был пытаться оставить о себе память в виде новых росписей в церкви или обновления старых, что и нашло отражение в последних двух периодах стенописи. Отметим, что мангупский дворец основательно перестраивался в 50-60-е гг. XV в. [10, c. 57]. По мнению В.П. Кирилко, тогда же в его современном виде возводится донжон цитадели [14, с. 229]. 


\section{ПРИЛОЖЕНИЕ}

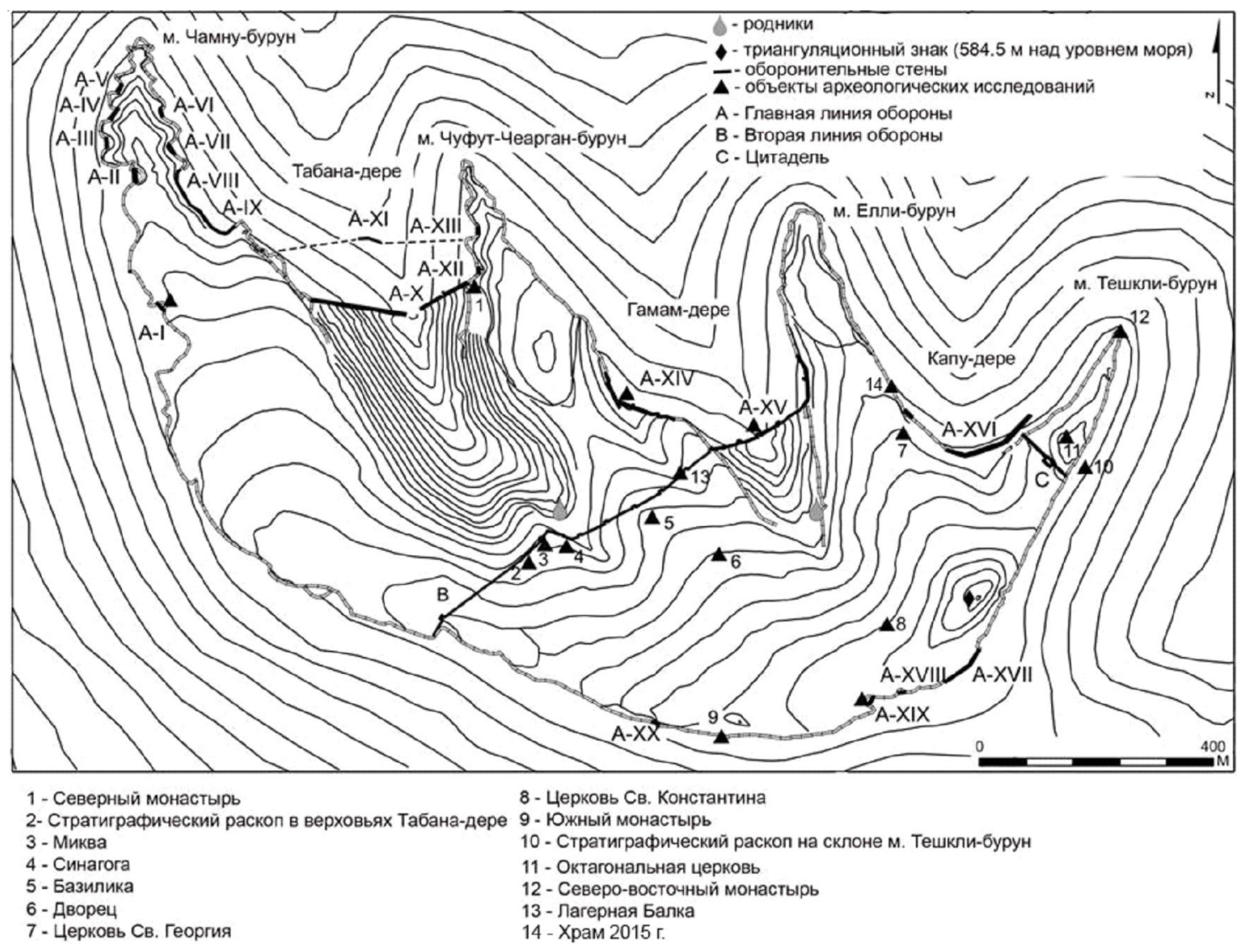

Рис. 1. План Мангупа с указанием основных памятников (по А.Г. Герцену)

Fig. 1. Plan of Mangup indicating the location of significant monuments (according to A.G. Herzen)

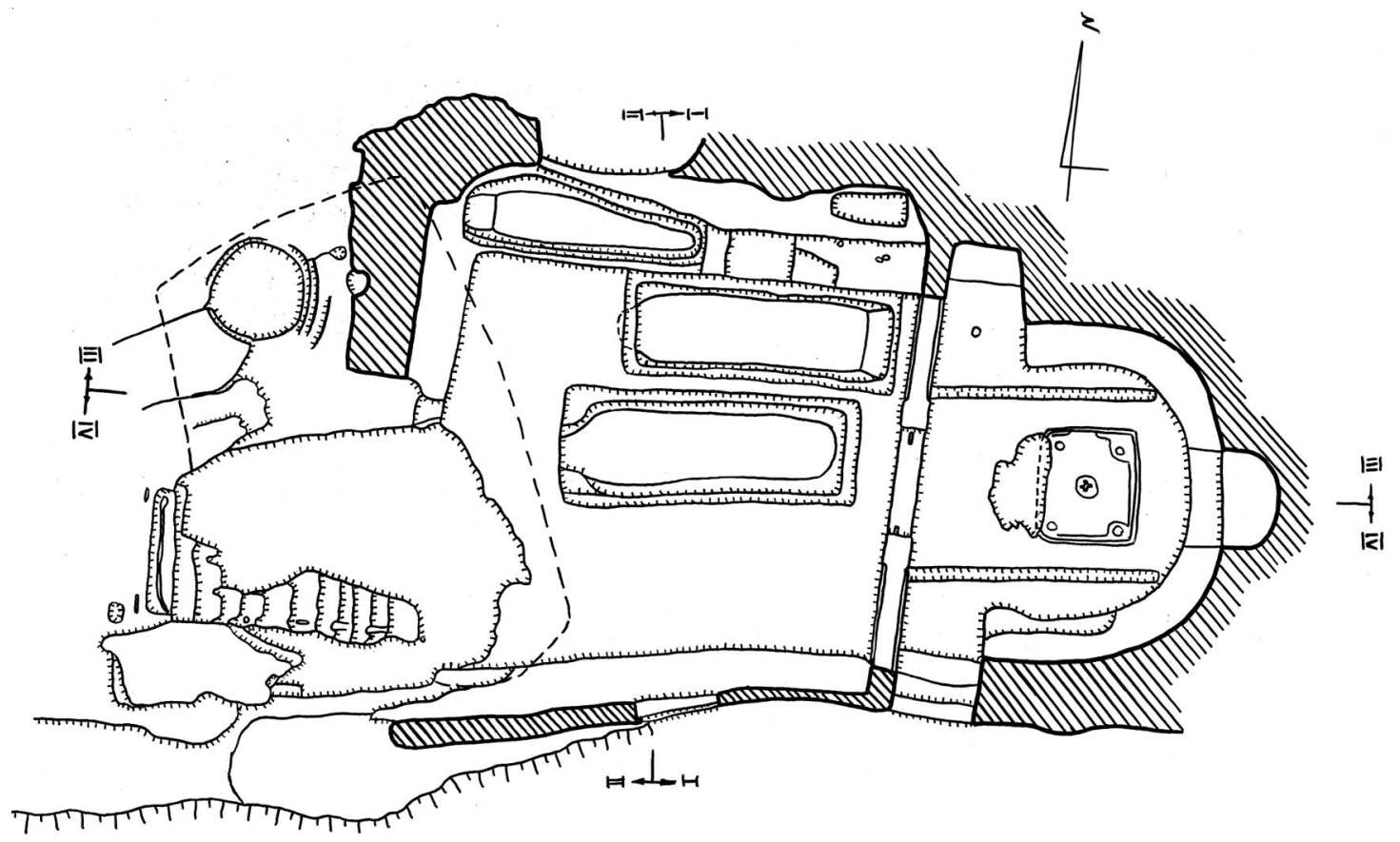

Рис. 2. Мангуп. Южный монастырь. Церковь. План

Fig. 2. Mangup. Southern Monastery. Church. Plan 
К вопросу о периодизации фресковых росписей пещерной церкви Южного монастыря Мангупа

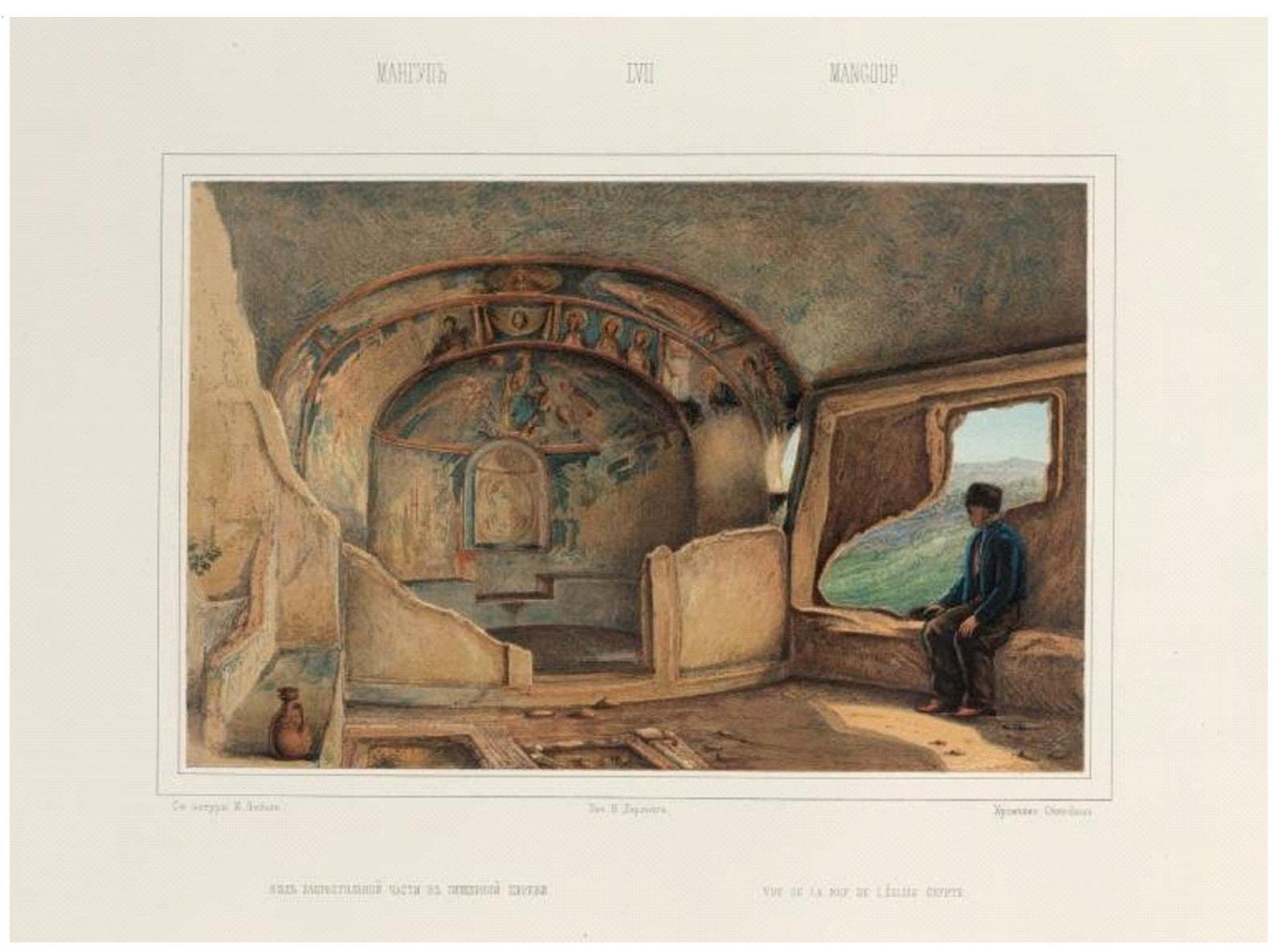

Рис. 3. Мангуп. Южный монастырь. Церковь. Из неизданного альбома А.С. Уварова Fig. 3. Mangup. Southern Monastery. Church. From the unpublished album of A.S. Uvarov 


\section{ВИЗАНТИЙСКАЯ ТАВРИКА}

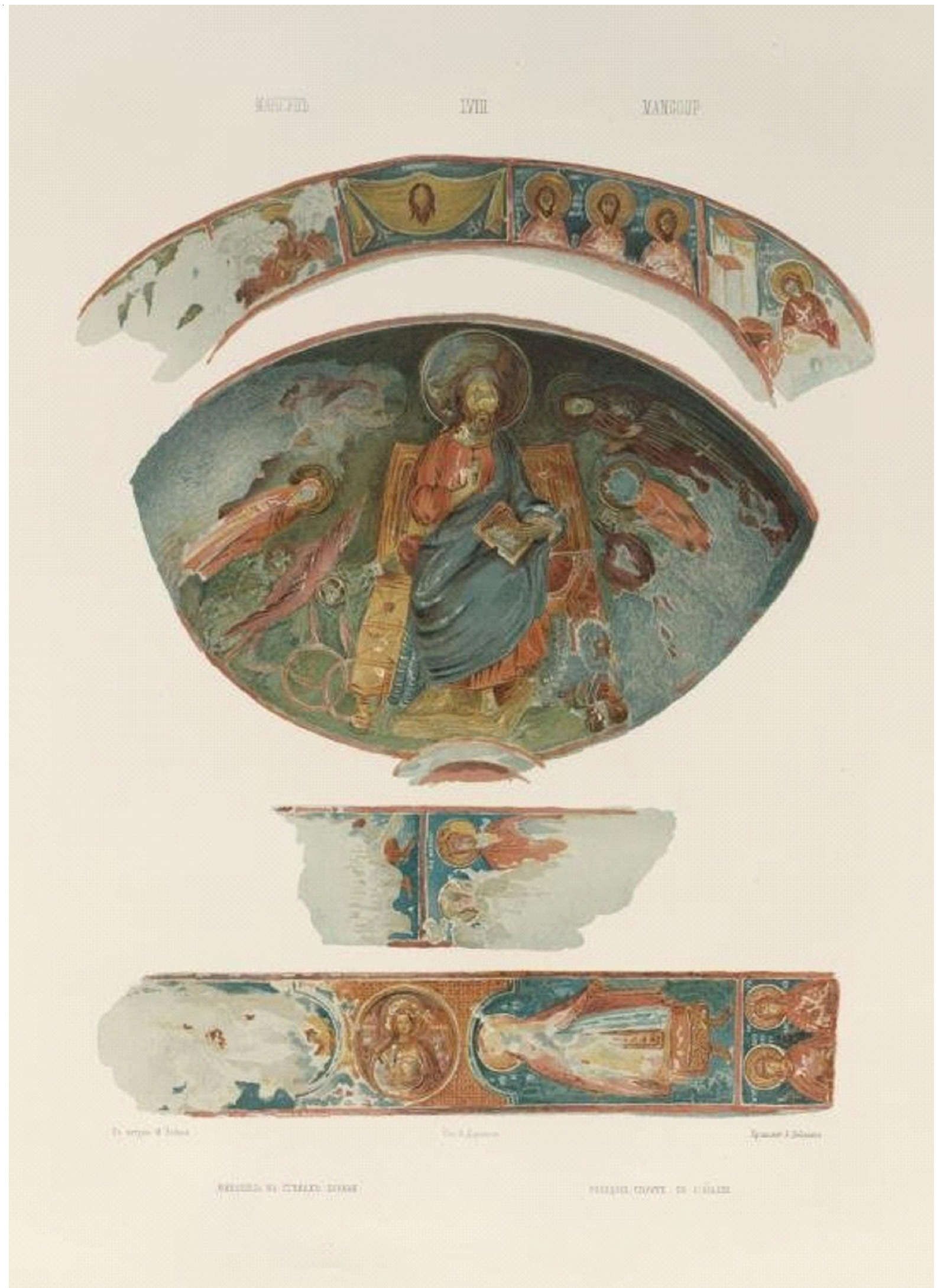

Рис. 4. Мангуп. Южный монастырь. Церковь. Фресковые росписи. Из неизданного альбома А.С. Уварова Fig. 4. Mangup. Southern Monastery. Church. Fresco paintings. From the unpublished album of A.S. Uvarov 


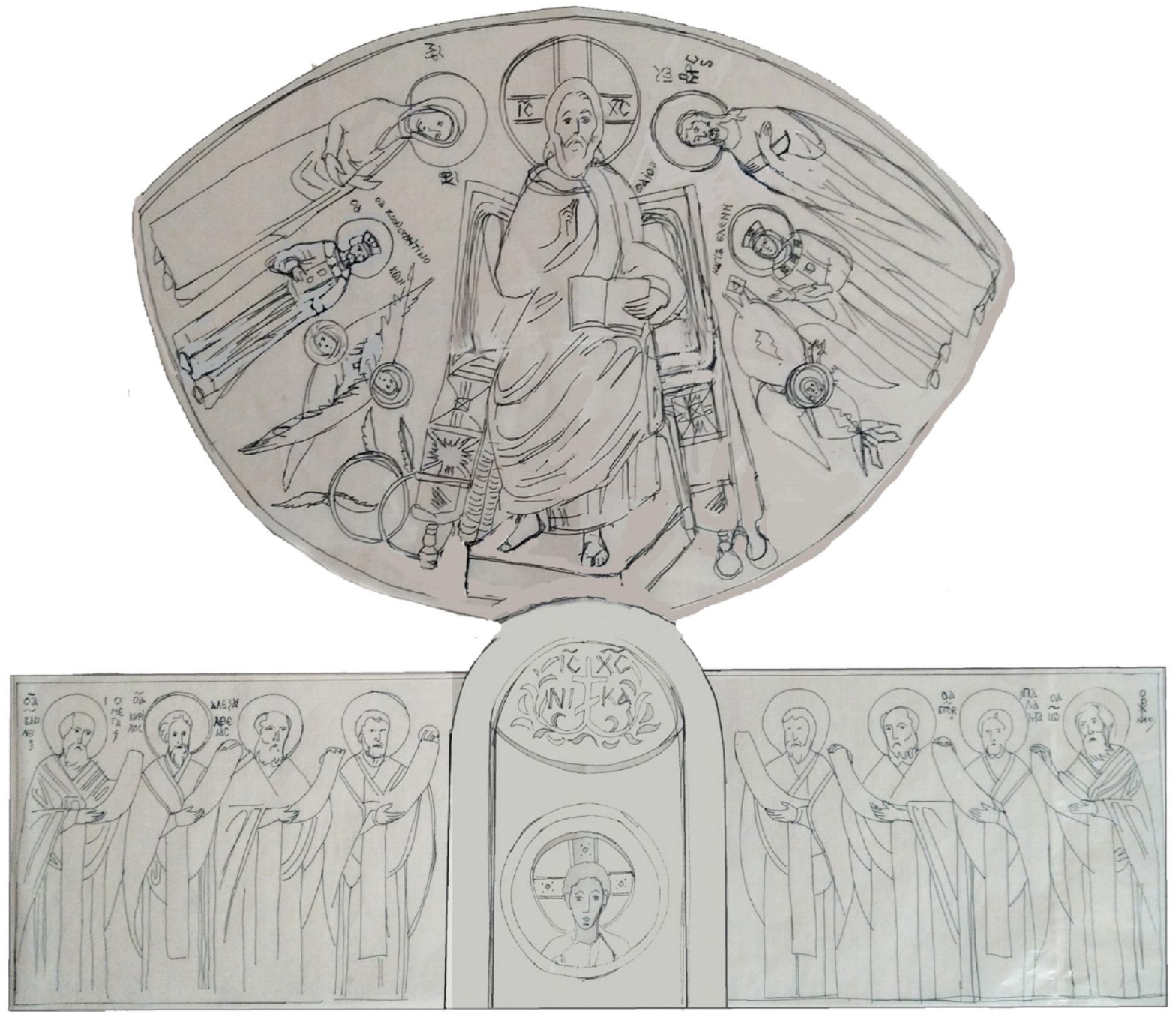

Рис. 5. Схема-реконструкция композиции апсиды церкви Южного монастыря Мангупа. Рисунок А.С. Ергиной

Fig. 5. Scheme-reconstruction of the apse composition of the church of the Southern Mangup Monastery. Drawing by A.S. Ergina 


\section{ВИЗАНТИЙСКАЯ ТАВРИКА}

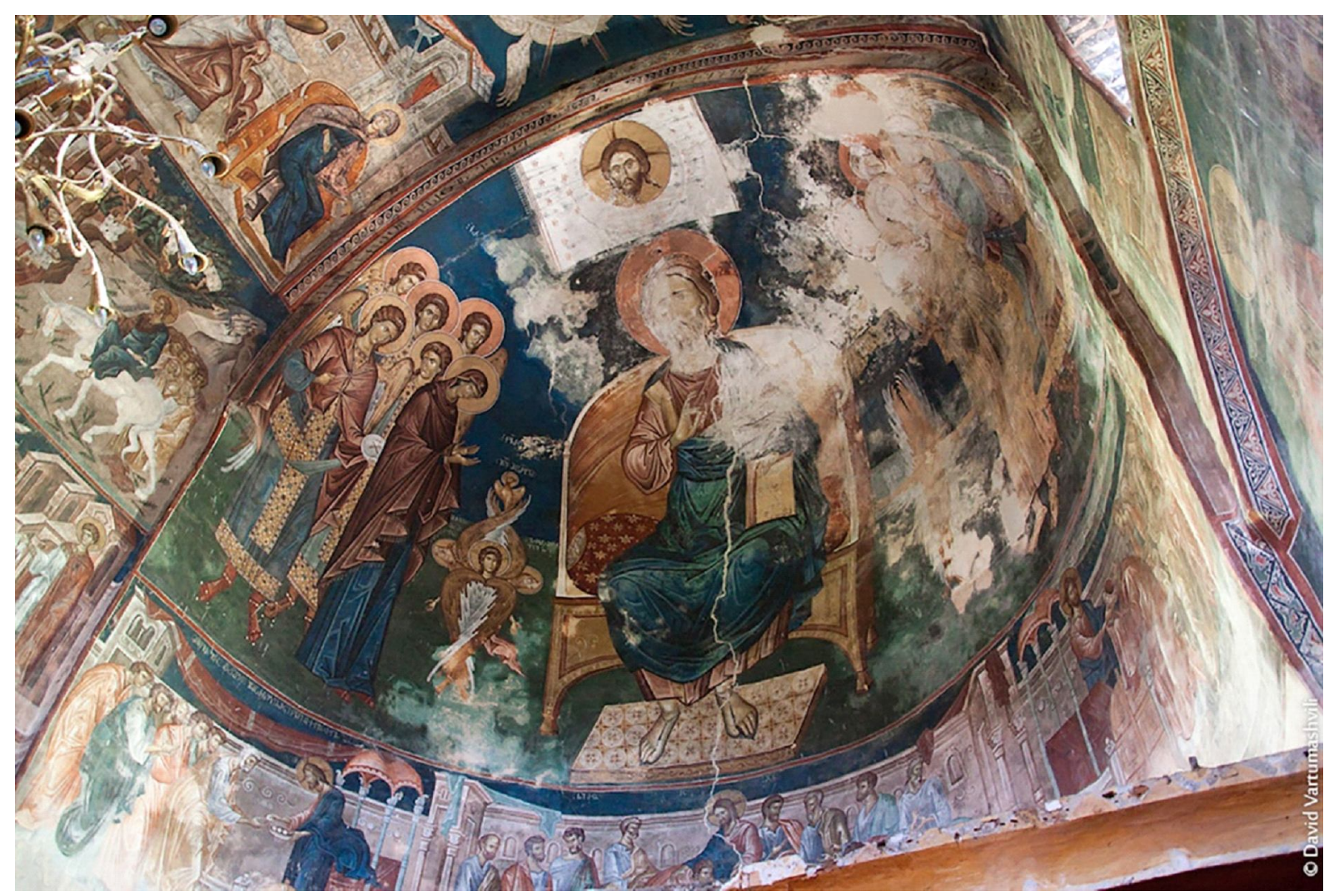

Рис. 6. «Деисус» в монастыре Убиси. Грузия. Фреска. Конец XIV в.

Fig. 6. Deesis from the Ubisi Monastery. Georgia. Fresco. Late $14^{\text {th }}$ century 


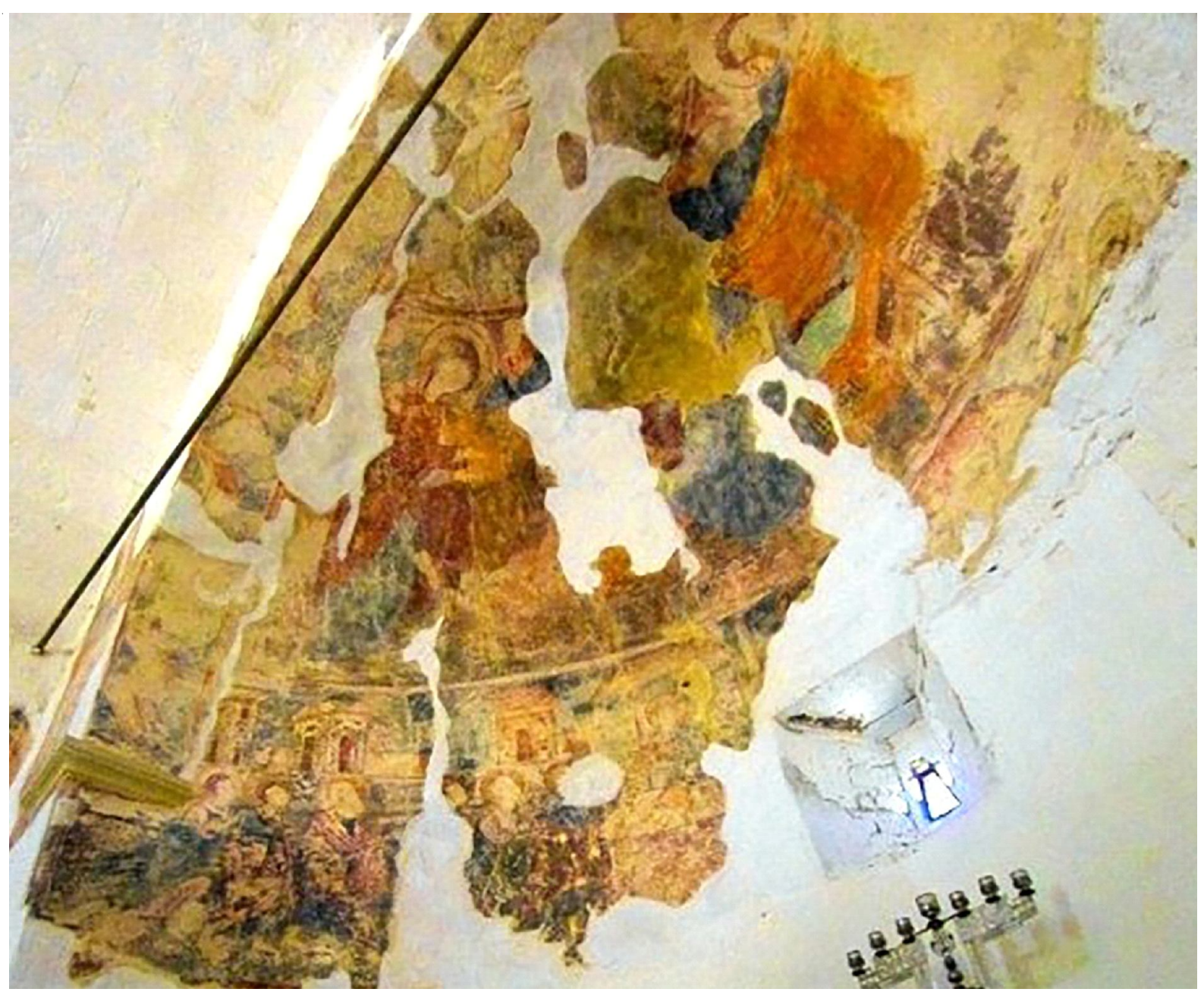

Рис. 7. «Деисус» в церкви Дмитрия Солунского. Феодосия (Каффа). Фреска. XIV в.

Fig. 7. Deesis from the Church of Dmitry Solunsky. Feodosia (Kaffa). Fresco. $14^{\text {th }}$ century 


\section{ВИЗАНТИЙСКАЯ ТАВРИКА}

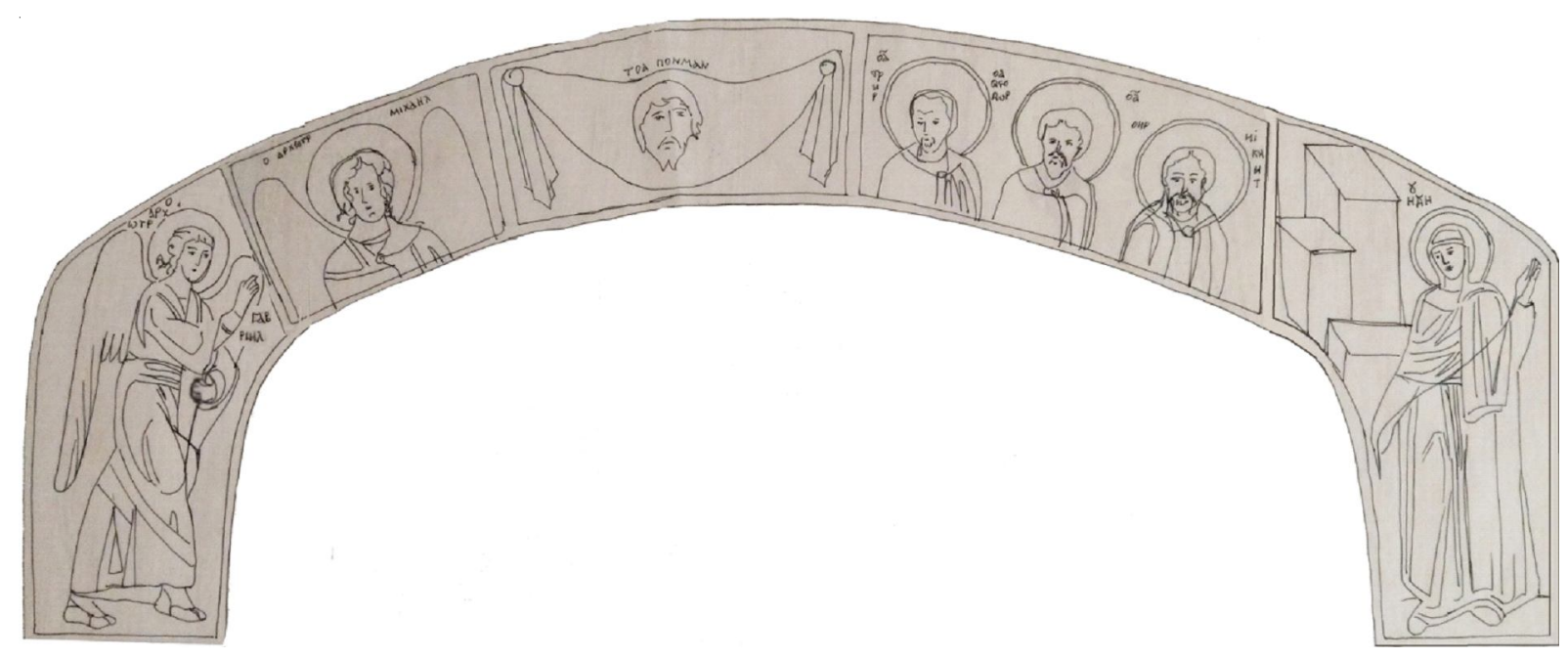

Рис. 8. Схема-реконструкция изображений карниза алтарной арки церкви Южного монастыря Мангупа. Рисунок А.С. Ергиной

Fig. 8. Scheme-reconstruction of the altar arch eave from the Church of the Southern Mangup Monastery. Drawing by A.S. Ergina

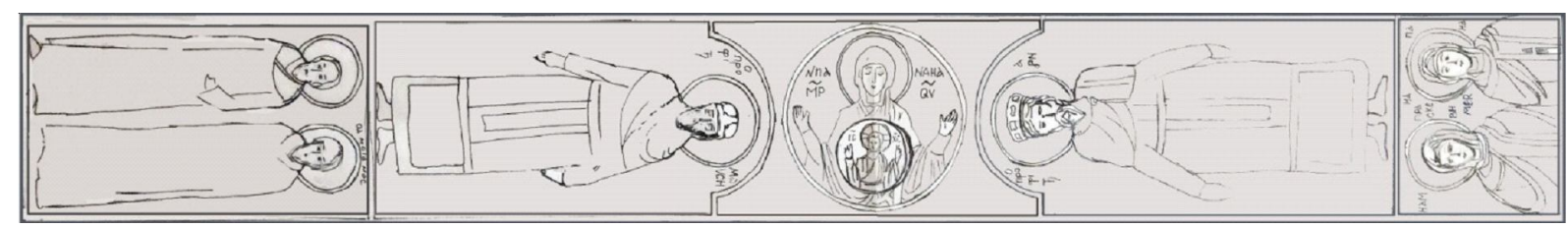

Рис. 9. Схема-реконструкция изображений святых на сводах церкви Южного монастыря Мангупа. Рисунок А.С. Ергиной

Fig. 9. Scheme-reconstruction of paintings of saints in the arches of the Church of the Southern Mangup Monastery. Drawing by A.S. Ergina 


\section{СПИСОК ЛИТЕРАТУРЫ}

1. Герцен, А. Г. Крепостной ансамбль Мангупа / А. Г. Герцен // Материалы по археологии, истории и этнографии Таврии. - 1990. - Вып. I. С. 87-166, 242-271.

2. Герцен, А. Г. Пещерные церкви Мангупа / А. Г. Герцен, Ю. М. Могаричев - Симферополь : Таврия, 1996. - $128 \mathrm{c}$.

3. Герцен, А. Г. Описание Мангупа-Феодоро в поэме иеромонаха Матфея / А. Г. Герцен // Материалы по археологии, истории и этнографии Таврии. - 2003. - Вып. Х. - С. 562-589.

4. Герцен, А. Г. Дорос - Феодоро (Мангуп): от ранневизантийской крепости к феодальному городу / А. Г. Герцен // Античная древность и средние века. - 2003. - Вып. 34. - С. 94-112.

5. Герцен, А. Г. Херсон и его округа в конце XХІ вв. «Пещерные города» / А. Г. Герцен, Ю. М. Могаричев // Русский исторический сборник. Вып. 8. Средневековый Херсон X-ХІ вв. / авт.-сост. А. В. Сазанов. - М. : Евролинц-Киммерийский центр, 2014. C. $435-484$.

6. Герцен, А. Г. К вопросу о выделении золотоордынского периода в истории Мангупского городища в Юго-Западном Крыму / А. Г. Герцен, В. Е. Науменко // Золотоордынская цивилизация. 2016. - № 9. - С. 247-258.

7. Герцен, А. Г. Княжество Феодоро: от «альфы» до «омеги» / А. Г. Герцен // Материалы по археологии, истории и этнографии Таврии. - 2017. Вып. XXII. - С. 348-368.

8. Герцен, А. Г. Пещерные сооружения Мангупа / А. Г. Герцен, Ю. М. Могаричев // Ученые записки Крымского федерального университета им. В.И. Вернадского. Исторические науки. -2017. T. 3 (69), № 3. - С. 102-129.

9. Герцен, А. Г. Мангуп в описании А.С. Уварова / А. Г. Герцен, Ю. М. Могаричев // История и археология Крыма. - 2017. - № VI. - C. 177-207.

10. Герцен, А. Г. Княжеский дворец Мангупского городища. Стратиграфия участка исследований 2006-2017 гг. / А. Г. Герцен, В. Е. Науменко, А. А. Ду-

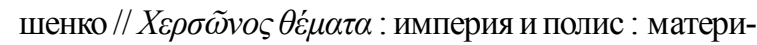
алы науч. конф. -2018. - Вып. Х. - С. 53-58.

11. Грабарь, И. Э. О древнерусском искусстве. Исследование, реставрация и охрана памятников / И. Э. Грабарь. - М. : Наука, 1966. - 386 с.

12. Дело Императорской археологической комиссии о древнем христианском храме, открытом на горе Мангуп, близ города Бахчисарая Таврической губернии //Архив Института истории материальной культуры РАН. - Ф. 1. - Д. 104. - 38 л.

13. Домбровский, О. И. Фрески средневекового Крыма / О. И. Домбровский. - Киев : Изд-во АН УССР, 1966. - $110 \mathrm{c}$.
14. Кирилко, В. П. Крепостной ансамбль Фуны 1423-1475 гг. / В. П. Кирилко. - Киев : Изд-во Стилос, 2005. -269 с.

15. Крым. Путеводитель. Ч. І. Очерки Крыма / под ред. К. Ю. Бумберга, Л. С. Вагина, Н. Н. Клепинина, В. В. Соколова. - Симферополь : Тип. Тавр. Губ. Земства, 1914. - 688 с.

16. Латышев, В. В. Заметки к христианским надписям из Крыма (по сообщению А.Л. БертьеДелагарда) / В. В. Латышев // Записки Одесского общества истории и древностей. - 1897. - Т. ХХ. C. $149-162$.

17. Маркевич, А. И. Экскурсия на Мангуп / А. И. Маркевич // Известия Таврической ученой архивной комиссии. - 1890. - № 9. - С. 101-107.

18. Могаричев, Ю. М. Пещерные сооружения средневековых городищ Юго-Западного Крыма (вопросы классификации, хронологии, интерпретации) / Ю. М. Могаричев // Проблемы истории «пещерных городов» в Крыму. - Симферополь : Таврия, 1992. - С. 5-132.

19. Могаричев, Ю. М. Пещерные церкви Таврики / Ю. М. Могаричев. - Симферополь : Таврия, 1997. $-384 \mathrm{c}$.

20. Могаричев, Ю. М. «Пещерные города» в Крыму / Ю. М. Могаричев. - Симферополь : Сонат, 2005. - 192 c.

21. Могаричев, Ю. М. Скальные церкви Горного Юго-Западного Крыма / Ю. М. Могаричев // Наследство и културен пейзаж. Известия регионален исторически музей Русе. - 2015. - Кн. XVIII. C. $67-104$.

22. Мошков, В. М. Пластическая основа композиции (проблемы синтеза искусств) / В. М. Мошков, О. И. Кузнецов - СПб. : Изд-во Санкт-Петербургского университета, 1994. - 80 с.

23. Осауленко, Є.М. Відображення візантійської аскетичної естетики в мистецтві Кримської Готії початку XV століття на прикладі розписів печерної церкви "Південного монастиря" на Мангупі / Є. М. Осауленко // Лаврський альманах. - 2007. Вип. 17.-С. 92-111.

24. Попов, А. Н. Вторая учебная экскурсия Симферопольской мужской гимназии в Бахчисарай и его окрестности / А. Н. Попов. - Симферополь : Тавр. губ. тип., 1888. - 131 с.

25. Протоколы заседаний ТУАК от 26.08.1911 // Известия Таврической ученой архивной комиссии. - 1912. - № 47. - С. 29-40.

26. Репников, Н. И. Материалы к археологической карте Юго-Западного нагорья Крыма / Н. И. Репников // Архив Институга истории материальной культуры РАН. - Ф. 10. - Д. 10. - 387 л.

27. Руев, В. Л. Турецкое вторжение в Крым в 1475 г. / В. Л. Руев. - Симферополь : Антиква, 2014. $-306 \mathrm{c}$. 
28. Степаненко, В. П. К реконструкции мангупской базилики на рубеже XIV-XV вв. / В. П. Степаненко // Ученые записки Крымского федерального университета им. В.И. Вернадского. Исторические науки. - 2018. - Т. 4 (70), № 3. - С. 106-117.

\section{REFERENCES}

1. Gertsen A.G. Krepostnoy ansambl Mangupa [The Ensemble of Fortifications at Mangup]. Materialy po arkheologii, istorii i etnografii Tavrii [Materials in Archeology, History and Ethnography of Tauria], 1990, iss. I, pp. 87-166, 242-271.

2. Gertsen A.G., Mogarichev Yu.M. Peshchernye tserkvi Mangupa [Cave Churches of Mangup]. Simferopol, Tavriya Publ., 1996. 128 p.

3. Gertsen A.G. Opisanie Mangupa-Feodoro v poeme ieromonakha Matfeya [Mangup - Theodora at the End of the $14^{\text {th }}$ Century in the Descriptions by Celibate Priest Matthew]. Materialy po arkheologii, istorii i etnografii Tavrii [Materials in Archeology, History and Ethnography of Tauria], 2003, iss. X, pp. 562-589.

4. Gertsen A.G. Doros - Feodoro (Mangup): ot rannevizantiyskoy kreposti $\mathrm{k}$ feodalnomu gorodu [Theodoro (Mangup): From the Early Byzantine Fortress to the Feudal City]. Antichnaya drevnost $i$ srednie veka, 2003, iss. 34, pp. 94-112.

5. Gertsen A.G., Mogarichev Yu.M. Kherson i ego okruga v kontse X-XI vv. "Peshchernye goroda" [Kherson and Its Districts at the End of the $10^{\text {th }}-11^{\text {th }}$ Centuries. "Cave Cities"]. Sazanov A.V., ed. Russkiy istoricheskiy sbornik. Vol. 8. Srednevekovyy Kherson $X-X I v v$. [Russian Historical Collection. Medieval Kherson of the $10^{\text {th }}-11^{\text {th }}$ Centuries]. Moscow, Evrolints-Kimmeriyskiy tsentr, 2014, pp. 435-484.

6. Gertsen A.G., Naumenko V.E. K voprosu o vydelenii zolotoordynskogo perioda $\mathrm{V}$ istorii Mangupskogo gorodishcha v Yugo-Zapadnom Krymu [To the Issue of the Allocation of the Golden Horde Period in the History of Mangup Settlement in the South-Western Crimea]. Zolotoordynskaya tsivilizatsiya [Golden Horde Civilization], 2016, no. 9, pp. 247-258.

7. Gertsen A.G. Knyazhestvo Feodoro: ot «alfy» do «omegi» [Theodoro Principality: From Alpha to Omega]. Materialy po arkheologii, istorii i etnografii Tavrii [Materials in Archeology, History and Ethnography of Tauria], 2017, iss. XXII, pp. 348-368.

8. Gertsen A.G., Mogarichev Yu.M. Peshchernye sooruzheniya Mangupa [The Cave Constructions of Mangup]. Uchenye zapiski Krymskogo federalnogo universiteta im. V.I. Vernadskogo. Istoricheskie nauki [Scientific Notes of V.I. Vernadsky Crimean Federal University. Historical Science], 2017, vol. 3 (69), no. 3, pp. 102-129.
9. Gertsen A.G., Mogarichev Yu.M. Mangup v opisanii A.S. Uvarova [Mangup in the Description of A.S. Uvarov]. Istoriya i arkheologiya Kryma [History and Archeology of Crimea], 2017, no. VI, pp. 177-207.

10. Gertsen A.G., Naumenko V.E., Dushenko A.A. Knyazheskiy dvorets Mangupskogo gorodishcha. Stratigrafiya uchastka issledovaniy 2006-2017 gg. [Princely Palace of Mangup Settlement. Research Site Stratigraphy 2006-2017]. Chersonos themata: imperiya i polis: materialy nauch. konf. [Themes of Cherson: Empire and Polis. Materials of the Scientific Conference], 2018, iss. X, pp. 53-58.

11. Grabar I.E. O drevnerusskom iskusstve. Issledovanie, restavratsiya i okhrana pamyatnikov [About Old Russian Art. Study, Restoration and Protection of Monuments]. Moscow, Nauka Publ., 1966. $386 \mathrm{p}$.

12. Delo Imperatorskoy arkheologicheskoy komissii o drevnem khristianskom khrame otkrytom na gore Mangup, bliz goroda Bakhchisaraya Tavricheskoy gubernii [Case of the Imperial Archaeological Commission of the Ancient Christian Church Opened on Mangup Mountain, Near the City of Bakhchisarai, Taurida Province]. Arkhiv Instituta istorii materialnoy kultury RAN [Archive of the Institute of the History of Material Culture of the Russian Academy of Sciences], f. 1, d. 104, 381.

13. Dombrovskiy O.I. Freski srednevekovogo Kryma [Frescos of Medieval Crimea]. Kiev, Izd-vo AN USSR, 1966. $110 \mathrm{p}$.

14. Kirilko V.P. Krepostnoy ansambl Funy 1423$1475 \mathrm{gg}$. [Fortress Ensemble of the Funa of 14231475]. Kiev, Izd-vo Stilos, 2005. 269 p.

15. Bumberg K.Yu., Vagina L.S., Klepinina N.N., Sokolova V.V., eds. Krym. Putevoditel. Ch. I. Ocherki Kryma [Crimea. Guide. Part 1. Essays on Crimea]. Simferopol, Tipografiya Tavricheskogo Gubernskogo Zemstva, 1914. 688 p.

16. Latyshev V.V. Zametki k khristianskim nadpisyam iz Kryma (po soobshcheniyu A.L. BertyeDelagarda) [Notes to Christian Inscriptions from Crimea (According to A.L Bertier-Delagard)]. Zapiski Odesskogo obshchestva istorii i drevnostey, 1897, vol. XX, pp. 149-162.

17. Markevich A.I. Ekskursiya na Mangup [Excursion to Mangup]. Izvestiya Tavricheskoy uchenoy arkhivnoy komissii, 1890, no. 9, pp. 101-107.

18. Mogarichev Yu.M. Peshchernye sooruzheniya srednevekovykh gorodishch Yugo-Zapadnogo Kryma (voprosy klassifikatsii, khronologii, interpretatsii) [Cave Constructions of Medieval Hillforts of the Southwestern Crimea. Issues of Classification, Chronology and Interpretation]. Problemy istorii "peshchernykh gorodov" v Krymu [Problems of the "Cave Town" History in Crimea]. Simferopol, Tavriya Publ., 1992, pp. 5-132. 
19. Mogarichev Yu.M. Peshchernye tserkvi Tavriki [Cave Churches of Taurica]. Simferopol, Tavriya Publ., 1997. 384 p.

20. Mogarichev Yu.M. «Peshchernye goroda»v Krymu ["Cave Towns" in Crimea]. Simferopol, Sonat Publ., 2005. 192 p.

21. Mogarichev Yu.M. Skalnye tserkvi Gornogo Yugo-Zapadnogo Kryma [Rocky Churches of the Mountainous Southwestern Crimea]. Nasledstvo $i$ kulturen peyzazh. Izvestiya regionalen istoricheski muzey Ruse [Inheritance and Cultural Landscape. News of Historical Regional Museum Ruse], 2015, book XVIII, pp. 67-104.

22. Moshkov V.M., Kuznetsov O.I. Plasticheskaya osnova kompozitsii (problemy sinteza iskusstv) [Plastic Base of the Composition (Problems of Synthesis ofArts)]. Saint Petersburg, Izd-vo Sankt-Peterburgskogo universiteta, $1994.80 \mathrm{p}$.

23. Osaulenko E.M. Vidobrazhennia vizantiiskoi asketychnoi estetyky v mystetsvi Krymskoi Gotii pochatku XV stolittia na prykladi rozpysiv pechernoi tserkvy "Pivdennogo monastyria" na Mangupi [The Reflection of the Byzantine Ascetic Aesthetics in the Art of the Crimean Gothic Beginning of the Fifteenth Century on the Example of the Paintings of the Cave Church "Southern Monastery" in Mangup]. Lavrskiy almanakh [Lavra Almanac], 2007, iss. 17, pp. 92-111.
24. Popov A.N. Vtoraya uchebnaya ekskursiya Simferopolskoy muzhskoy gimnazii $v$ Bakhchisaray $i$ ego okrestnosti [The Second Study Tour of the Simferopol Male Gymnasium in Bakhchisarai and Its Surroundings]. Simferopol, Tavricheskaya gubernskaya tipografiya, $1888.131 \mathrm{p}$.

25. Protokoly zasedaniy TUAK ot 26.08.1911 [Minutes of Sessions of the Taurian Academic Archival Commission of August 26, 1911]. Izvestiya Tavricheskoy uchenoy arkhivnoy komissii, 1912, no. 47, pp. 29-40.

26. Repnikov N.I. Materialy k arkheologicheskoy karte Yugo-Zapadnogo nagorya Kryma [Materials on Archeological Map of the Southwestern Plateau of Crimea]. Arkhiv Instituta istorii materialnoy kultury RAN [Archive of the Institute of the History of Material Culture of the Russian Academy of Sciences], f. 10, d. 1, 387 l.

27. Ruev V.L. Turetskoe vtorzhenie v Krym v $1475 \mathrm{~g}$. [Turkish Invasion to Crimea in 1475]. Simferopol, Antikva Publ., 2014. 306 p.

28. Stepanenko V.P. K rekonstruktsii mangupskoy baziliki na rubezhe XIV-XV vv. [To the Reconstruction of the Mangup Basilica at the Turn of the XIV-XV Centuries]. Uchenye zapiski Krymskogo federalnogo universiteta im. V.I. Vernadskogo. Istoricheskie nauki [Scientific Notes of V.I. Vernadsky Crimean Federal University. Historical Science], 2018, vol. 4 (70), no. 3, pp. 106-117.

\section{Information about the Authors}

Yuriy M. Mogarichev, Doctor of Sciences (History), Professor, Leading Researcher, Institute of Archaeology of Crimea of the Russian Academy of Sciences, Prosp. Vernadskogo, 2, 295007 Simferopol, Russian Federation; Head of the Department of Social and Humanities Science, Crimean Republican Institute of Postgraduate Pedagogical Education, Lenina St., 15, 295000 Simferopol, Russian Federation, mogara@rambler.ru, https://orcid.org/0000-0001-6057-2316

Alena S. Ergina, Postgraduate Student, Department of Art History, Saint Petersburg Stieglitz State Academy of Art and Design, Solyanoy Lane, 13, 191028 Saint Petersburg, Russian Federation, yergina.alyona@gmail.com, https://orcid.org/0000-0001-7988-0415

\section{Информация об авторах}

Юрий Миронович Могаричев, доктор исторических наук, профессор, ведущий научный сотрудник, Институт археологии Крыма РАН, просп. Академика В.И. Вернадского, 2, 295007 г. Симферополь, Российская Федерация; заведующий кафедрой социального и гуманитарного образования, Крымский республиканский институт постдипломного педагогического образования, ул. Ленина, 15, 295000 г. Симферополь, Российская Федерация, mogara@rambler.ru, https://orcid.org/0000-0001-6057-2316

Алена Сергеевна Ергина, аспирант кафедры искусствоведения, Санкт-Петербургская государственная художественно-промышленная академия им. А.Л. Штиглица, Соляной пер., 13, 191028 г. Санкт-Петербург, Российская Федерация, yergina.alyona@gmail.com, https://orcid.org/0000-0001-7988-0415 